\title{
Characterization of the Leachate from the Municipal Landfill of Akouédo (Abidjan, Côte d'Ivoire)
}

\author{
Yoh Coulibaly $^{1^{*}} \quad$ Tiangoua Koné $^{1} \quad$ Mahamadou Kamagaté ${ }^{2} \quad$ Jean-Marie Petemanagnan Ouattara $^{1}$ \\ Sandotin Lassina Coulibaly ${ }^{1} \quad$ Lacina Coulibaly $^{1}$ \\ 1.University of Nangui Abrogoua, 01 BP 801 Abidjan 01, Abidjan (Côte d'Ivoire) \\ 2.University of Man, BP 20 Man, Man (Côte d'Ivoire)
}

\begin{abstract}
Municipal solid waste in developing countries especially in Africa are commonly managed by discharging in uncontrolled landfill. This leads to the generation of huge amounts of leachate that are rejected in the nature without any treatment. This study consisted in characterizing the leachate from the Landfill of Akouédo in the District of Abidjan (Côte d'Ivoire) despite the completion of filling operations in 2019. The physico-chemical composition of raw leachate suggested a stabilized landfill, with alkaline $\mathrm{pH}$ (i.e. $~ 8.85 \pm 0.03$ ). However, the concentrations of nutrients and organics such as $\mathrm{NH}_{4}^{+}\left(212.5 \pm 0.31 \mathrm{mg} . \mathrm{L}^{-1}\right), \mathrm{NO}_{2}^{-}\left(257.5 \pm 0.42 \mathrm{mg} . \mathrm{L}^{-1}\right), \mathrm{NO}_{3}^{-}\left(301.85 \pm 0.16 \mathrm{mg} . \mathrm{L}^{-1}\right)$, $\mathrm{BOD}_{5}\left(1015 \pm 0.12 \mathrm{mg} \mathrm{O}_{2} \mathrm{~L}^{-1}\right)$ et $\mathrm{COD}\left(9640 \pm 0.4 \mathrm{mg} \mathrm{O}_{2} \mathrm{~L}^{-1}\right)$ obtained in Landfill of Akouédo were slightly weak, compared to the FEPA's standard (1991). This could confirm the stabilization of the leachate, with a BOD 5 / COD ratio of around $0.1 \pm 0.05$. In addition, most of the metallic trace element contents (i.e. Iron, Copper, Nickel, Zinc and Lead) were below FEPA's standard (1991). To further investigate, humic acid (HA), fulvic acid (FA) and humin were extracted from the humic substance of this leachate. Thus, about $91 \%$ and $9 \%$ were obtained for humic acid and fulvic acid + humin, respectively. For better understanding, synthetic humic acid (SHA) was used as the reference material. The DRIFT analysis helped determine some difference between the LHAs of the leachate and SHA. However, the characteristics of the functional groups of the LHA and SHA molecules were essentially similar. The data on the characteristics of the HS shown in the results of the landfill leachate can be used in several related research areas, such as the optimization of leachate treatment processes and the remediation of groundwater contaminated with leachate.
\end{abstract}

Keywords: Municipal solid waste, Landfill, Leachate, humic substance, humic and fulvic acid.

DOI: $10.7176 / \mathrm{JEES} / 10-4-03$

Publication date: April $30^{\text {th }} 2020$

\section{Introduction}

The population growth causes an intensification of socio-economic activities (trade, industry, agriculture, etc.). This leads to an increase in solid waste generation. Thus, municipalities have to deal with huge amounts of solid waste. As an alternative, urban municipalities are developing waste recycling and waste to energy initiatives to reduce waste amounts and add value to waste management systems. However, in developing countries, the preferred way of solid waste management is disposing of in uncontrolled landfills (Zalaghi et al., 2014). The major and unavoidable concern with an uncontrolled landfill is the mismanagement of leachate that causes serious environmental issues (Baccini et al., 1987). Their rejection in the nature without any treatment results in pollution of soil, water and wildlife, greenhouse gas emissions, health impacts, etc. (Kouame et al., 2006; Sang et al., 2010; Zhao et al., 2012).

In Côte d'Ivoire, in the District of Abidjan, the uncontrolled landfill of Akouédo is among the perfect examples of bad waste management and their by-products such as leachate and biogas. There is no network of collection, storage and treatment leachate and biogas indeed. Yet the landfill of Akouédo generates a significant amount of leachate in the range of $474 \mathrm{~m}^{3} / \mathrm{d}$ that flows into the Ebrié Lagoon downstream (Adjiri et al., 2008). This situation has continued for the commissioning of the landfill Akouédo and leads to degradation of the water quality of the lagoon and the loss of ecosystem services. Given all these problems of contamination due to leachate, it is imperative to find out suitable and cost-effective treatment techniques of raw leachates from urban landfills.

However, before developing a treatment technique or technology a good knowledge of the content of leachate in terms of inorganic and organic matter is required.

Indeed, characterization studies conducted yet on the leachate from the landfill of Akouédo focused on the content of inorganic materials and organic matter determined as Biochemical Oxygen Demand (BOD) and Chemical Oxygen Demand (COD) (Kouame et al., 2006; Adjiri et al., 2008; Kouassi et al., 2014). So far, there is no scientific reference to the chemical nature of the organic matter contained in the leachate of the landfill of Akouédo.

It should however be noted that it is well known that humic substances $(\mathrm{SH})$ and volatile fatty acids are the main organic material in the landfill leachate (Tahiri et al., 2016). These organic substances are composed mainly of humic and fulvic acid which are refractory to biodegradation. The studies of Lagier (2000) and Labanowski (2004) found out that $80 \%$ of the dissolved organic carbon was comprised of type humic macromolecules to said 
leachate stabilized. This means that humic substances (HS) may be the major organic matter in landfill leachate.

Therefore, the overall goal of this study was to determine the relative content of humic and make a complete characterization of the leachate. More specifically, the study aimed at (i) to determining the physico-chemical characteristics of leachate from the landfill of Akouédo, (ii) to extract the crude humic substance and determine its composition in humic acid, fulvic acid and humin, and (iii) to compare the obtained humic acid in the leachate with humic acid purchased from Sigma Aldrich.

\section{Materials and methods}

\subsection{Location of the study area}

The District of Abidjan, has an estimated population of around 4,7 million, representing almost $21 \%$ of Côte d'Ivoire's national population (RGPH, 2014). The city of Abidjan is located at an average height of $10 \mathrm{~m}$ above the sea level and is surrounded by the Ebrié Lagoon. Spatially, this city covers an area of 2,119 $\mathrm{km}^{2}(\mathrm{i} . \mathrm{e} .0 .66 \%$ of country) (Yao-Kouassi, 2010) and experiences a mainly tropical climate with an annual rainfall estimated between 1,250 and 1,922 $\mathrm{mm}$ (Kouassi et al., 2018). The study area is the former main municipal landfill of the District of Abidjan, named Landfill of Akouédo which was built since 1965 and has an area of 153 ha. The Landfill of Akouédo which is uncontrolled is located at about $15 \mathrm{~km}$ from the center of Abidjan City. According to ANASUR, only 35 ha of the site received continuously waste from populations throughout the District of Abidjan since 1965 and reached saturation in 2004. Despite that, the waste continued to be piled up at the landfill until 2019 (Gevalor, 2015). It received domestic, industrial and institutional waste collected and transported by public and private waste management operators. Waste were then discharged in the Landfill of Akouédo without following any standard until the saturation of the site. As waste were piled up, 2 natural drains at the downstream of the landfill collected leachate that flowed from the landfill into a central pond, from which the leachate were discharged without any treatment into the Ebrié Lagoon (Figure 1).

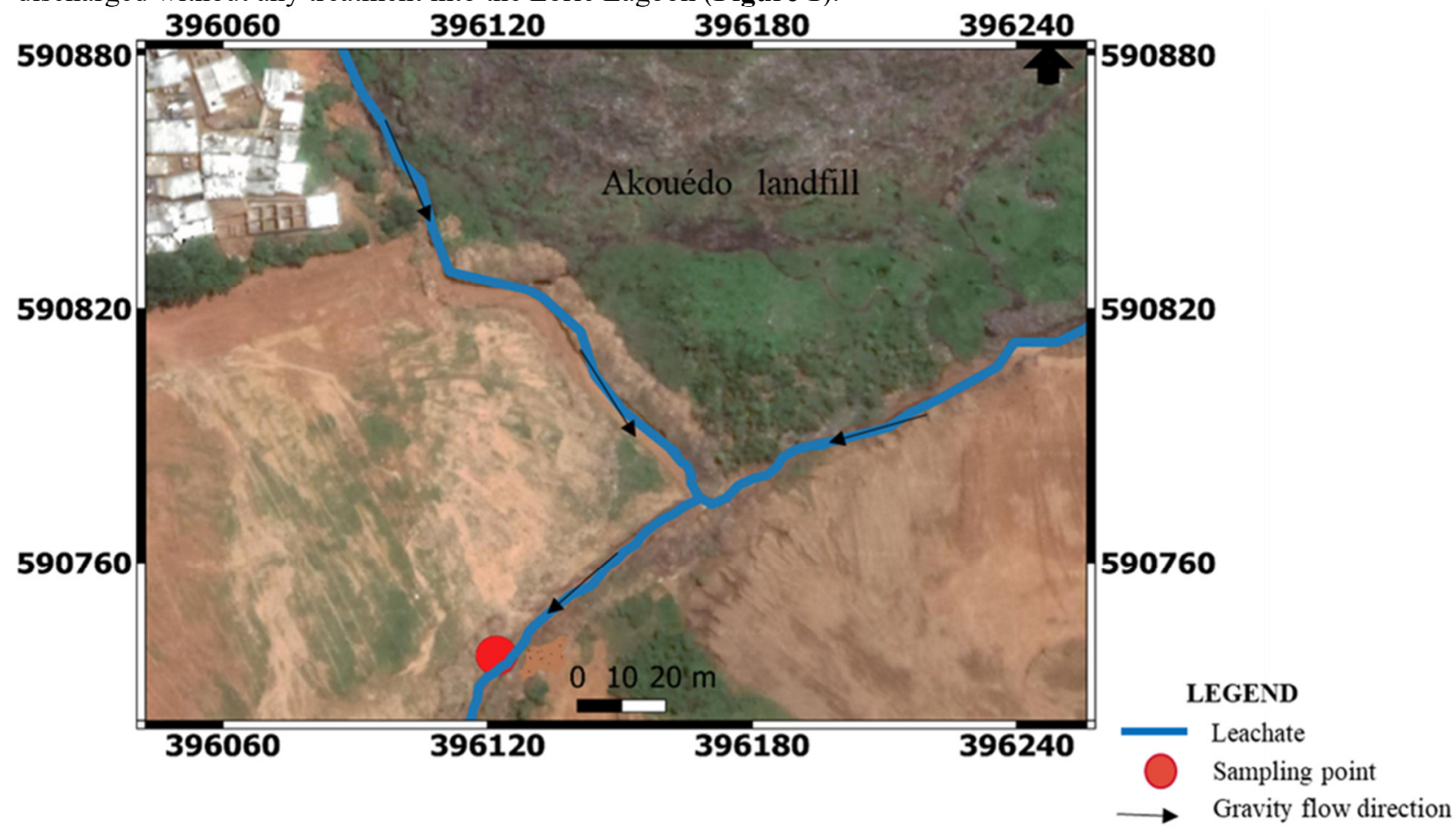

Figure 1: Mapping of the Landfill of Akouédo and the leachate stream.

\subsection{Chemicals}

Synthetic humic acid, sulfuric acid $\left(\mathrm{H}_{2} \mathrm{SO}_{4}\right)$, Hydrochloric acid $(\mathrm{HCl})$ and Sodium Hydroxide $(\mathrm{NaOH})$ were purchased from Sigma-Aldrich ${ }^{\circledR}$ in France. All chemicals used were of pro-analytical quality or better.

\subsection{Leachate sampling and analyses}

Leachate sampling was carried out at the leachate stream outlet. To avoid dilution effects, leachate sampling was performed during dry season, and the leachate samples were collected in well-labeled polyethylen bottles. Analytical methods were compliant with "AFNOR Standard water and wastewater analysis methods" (AFNOR, 1990). One duplicate was acidified to $\mathrm{pH} 2$ by addition of $100 \mathrm{~mL}$ of $10 \mathrm{M} \mathrm{HCl}$ solution to each $100 \mathrm{~mL}$ sample and used for determination of metals, nitrogen (ammonia, nitrite and nitrate) and phosphorous (as phosphate). The 
second duplicate was kept at its natural $\mathrm{pH}$ and used for determination of conductivity and organic matter (Chemical Oxygen Demand, COD, and Biochemical Oxygen Demand, BOD). Conductivity and $\mathrm{pH}$ were measured in situ using Electrochemical probe method according to NFT 90-008 and NFT 90-031 standards, respectively, whereas Suspended Solids (SS) were determined with NFT 90-105 standard. The results are expressed in $\mathrm{mg} \mathrm{L}^{-1}$. Temperature was also determined using a Cobra 4 Mobile-Link thermometer. Molecular absorption spectrometry methods were used to analyze nitrite $\left(\mathrm{NO}_{2}^{-}\right)$, nitrate $\left(\mathrm{NO}_{3}^{-}\right)$, ammonium $\left(\mathrm{NH}_{4}^{+}\right)$and phosphates ( $\mathrm{PO}_{4}^{3-}$ ) according to NFT 90-13, NFT 90-45, NFT 90-15 standards respectively. An Atomic Absorption Spectrophotometer was used for metal (i.e. Copper (Cu), Nickel (Ni), Lead (Pb), Iron (Fe) and Zinc (Zn)) analysis after sample acid digestion. In fact, these metals are most commonly found in household leachate. The BOD 5 was measured using the Oxitop method (Reuschenbach et al., 2003), while COD was determined by the dichromate reduction method (APHA, 1989 ; ISO, 1989) employing Hach $^{\circledR}$ COD digestion vials (Hach, 2015).

\subsubsection{Humic substance (HS) extraction}

Extraction of HS from the leachates was performed by acid-base treatment method proposed by Thurman and Malcolm (1981) and modified by Tahiri et al. (2016). Briefly, $20 \mathrm{~mL}$ of leachate samples, previously filtered in order to retain the Suspended solids, was adjusted to $\mathrm{pH}$ between 10 and 11 by adding $1 \mathrm{~N} \mathrm{NaOH}$ solution, which caused the metals and dissolved humic acid precipitation. After $3 \mathrm{~h}$ of stirring, the solution was centrifuged at 4000 rpm for 45 minutes. The supernatant leachate (i.e. humic substances), containing humic acid (HA), fulvic acid (FA) and humin was collected. The leachate samples were centrifuged and filtered through glass-fiber filter paper (i.e. $0.45 \mu \mathrm{m})$ to remove suspended materials that may react with HS. The extracted HS were separated into humic and fulvic acid fractions by acidifying (e.g. sulfuric acid, $\mathrm{H}_{2} \mathrm{SO}_{4}$ ) the HS solution to $\mathrm{pH} 1.0$ and precipitating humic acid fraction. The resulting humic acid pellets were filter and dried and weighed to determine the humic acid mass corresponding to the volume of crude leachate used. Supernatant samples were used to determine the COD content, which represents the residual humic acid. COD of the supernatant was determined as above. All the experiments were carried out in triplicate.

\subsubsection{Diffuse Reflectance InfraRed Fourier Transform Spectroscopy}

Diffuse Reflectance InfraRed Fourier Transform (DRIFT) spectra were recorded between in the 400 and $4000 \mathrm{~cm}^{-1}$ regions with a IS50 Nicolet spectrometer equipped with a KBr beam splitter and a TCD detector. A powdered sample is mixed with $\mathrm{KBr}$ powder. The DRIFT cell reflects radiation to the powder and collects the energy reflected back over a large angle. Diffusely scattered light can be collected directly from material in a sampling cup or, alternatively, from material collected by using an abrasive sampling pad. DRIFT is particularly useful for sampling powders or fibres. The resolution of the single beam spectra was $4 \mathrm{~cm}^{-1}$. The pellets of synthetic humic acid and that provided from leachate were used for DRIFT. For quantitative analysis, where spectral absorption is required to follow Beer's law, or where direct comparison with pressed $\mathrm{KBr}$ disc spectra is required, the nonlinear intensities can be partly corrected by application of the Kubelka-Munk function (1) (Hecht, 1980; Griffiths and Fuller, 1982). DRIFT spectra were then recorded immediately.

Where:

$$
A(K M)=\frac{2 R}{(1-R)^{2}}=\frac{a^{\circ}}{S}
$$

- $\mathrm{A}(\mathrm{KM})$ is the required intensity in Kubelka-Munk (KM) units,

- $\mathrm{R}$ is the observed reflectivity, for infinite sample thickness, relative to a non-absorbing matrix, $\mathrm{a}$ is the absorptivity due to volume reflection, and

- $\mathrm{s}$, is the scattering coefficient.

\section{Results and discussion}

\subsection{Physico-chemical composition}

Table 1 shows the Physico-chemical composition of the raw leachate of the Landfill of Akouédo. Indeed, alkaline leachate was observed, with $\mathrm{pH}$ value $\sim 8.85 \pm 0.03$, thereby underscoring the Landfill of Akouédo is exploited for a long period (i.e. sample provide from aged wastes) (Talalaj, 1998). However, alkaline leachate was also obtained from several landfills such as the municipal solid waste landfill site in Ibadan, Nigeria (Aluko et al., 2003). Although the characteristics of landfill leachate depend on several parameters (i.e. the type of wastes dumped, the solid waste stabilization degree, hydrology site, moisture content, seasonal weather variations, landfill age and stage of the decomposition in the landfill) (Wang et al., 2003), the common characteristics of stabilized leachate are high resistance of $\mathrm{NH}_{3}-\mathrm{N}\left(3,000-5,000 \mathrm{mg} . \mathrm{L}^{-1}\right)$ and $\mathrm{COD}\left(5,000-20,000 \mathrm{mg} . \mathrm{L}^{-1}\right)$, as well as a low ratio of $\mathrm{BOD} / \mathrm{COD}$ (i.e. less than 0.1 ) (Li et al., 2002). Unlike the literature, the values of $\mathrm{NH}_{4}^{+}(212.5 \pm 0.31$ $\left.\mathrm{mg} . \mathrm{L}^{-1}\right), \mathrm{NO}_{2}^{-}\left(257.5 \pm 0.42 \mathrm{mg} . \mathrm{L}^{-1}\right), \mathrm{NO}_{3}^{-}\left(301.85 \pm 0.16 \mathrm{mg} \cdot \mathrm{L}^{-1}\right)$ et COD $\left(9640 \pm 0.4 \mathrm{mg} \mathrm{O}_{2} \mathrm{~L}^{-1}\right)$ obtained within the Landfill of Akouédo were widely weak, despite the completion of filling operations. All these values exceeded the FEPA's standard (1991) (Table 1). The BOD5 / COD ratio was approximately $0.1 \pm 0.05$, thus confirming the stabilization of leachate and its biodegradability (Kouassi et al., 2014 ; Naveen et al., 2017). Unlike the present 
study, where the $\mathrm{BOD}_{5} / \mathrm{COD}$ values of the leachate samples were ranking between 0.1 and 0.5 . The studies performed by Chian and Dewalle (1976), reported $\mathrm{BOD}_{5} / \mathrm{COD}$ values from 0.5 to 0.7 , thereby emphasizing the presence of large amounts of biodegradable organic matter. This could cause contamination by chemical species in dissolved or suspended forms of the environment (Kurniawan et al., 2006). In this study, phosphate content (i.e. $3.12 \pm 0.51 \mathrm{mg} \mathrm{L}^{-1}$ ) was below FEPA's standard values (i.e. $5 \mathrm{mg} \mathrm{L}^{-1}$ ) (See Table 1), but knowledge of the nitrates and phosphates contents is important to predict the nutritive state of the waters, since these ions are important nutrients for plants which generally appear following the decomposition and mineralization of organic matter (Naveen et al., 2017). Otherwise, most of the metallic trace element contents (i.e. Iron, Copper, Nickel, Zinc and Lead) were below FEPA's standard (See Table 1), as well as some literature values (Aluko et al., 2003) and identical to those of Naveen et al. (2017).

Table 1: Physico-chemical characteristics of leachate from the Landfill of Akouédo (Abidjan, Côte d'Ivoire)

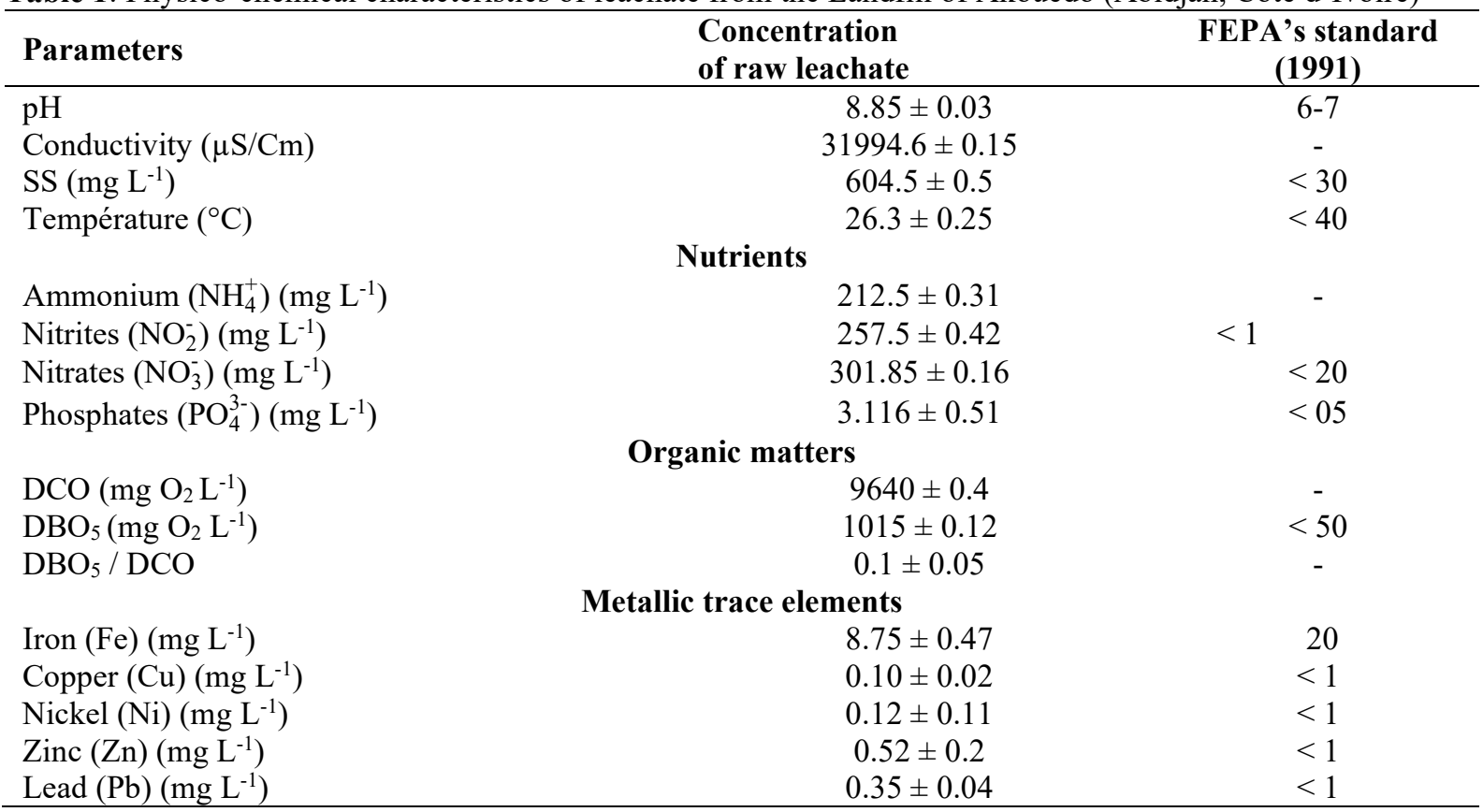

\subsection{Humic and Fulvic acids in leachate of the Landfill of Akouédo}

Table 2 exhibits the essential fractions of humic substance (HS) contained in the leachate from the Landfill of Akouédo. These are humic acid (HA), fulvic acid (FA) and humin (H). Indeed, a large amount of HA (i.e. $91 \%$ ) compared to FA + H (i.e. 9\%) was obtained in the leachate (See Table 2). According to Castagnoli et al. (1990), the predominance of humic acid is probably due to the stabilization and non-homogeneity of waste in the landfill. The FA/HA ratio value (i.e. 0.1) confirmed the previous results. In fact, Fan et al. (2006) also revealed a low FA/HA value (i.e. 0.36 vs 0.94) in the leachate of a landfill site in Central Taiwan, due to the lack of organic matter caused by the aging of the landfill.

Table 2: Concentrations of humic substance component in the leachate of the Landfill of Akouédo

\begin{tabular}{lccc|c} 
Components & HA & FA + H & HA + FA + H & FA/HA \\
\hline HS $\left(m g . L^{-1}\right)$ & 872 & 90 & 962 & 0.1 \\
Proportion (\%) & 90.64 & 9.36 & 100 & - \\
\hline
\end{tabular}

\subsection{DRIFT spectra analysis}

The DRIFT spectra of leachate humic acid (LHA) and synthetic humic acid (SHA) are illustrated in Figure 2. Indeed, these spectra provided information on specific molecular structures and various functional groups (Schnitzer and Khan, 1972). For instance, $3200-3400 \mathrm{~cm}^{-1}$ regions were assigned intermolecular O-H stretching or H-bounded $\mathrm{OH}$, whereas $2850-2980 \mathrm{~cm}^{-1}$ regions were ascribed asymmetrical and symmetrical stretching of methyl and methylene $\mathrm{C}-\mathrm{H}$ bond. Moreover, $2900-1720 \mathrm{~cm}^{-1}$ regions were attributed to aliphatic $\mathrm{C}-\mathrm{H}$ stretching, $\mathrm{C}-\mathrm{O}$ stretching in carboxylic acids and aldehydes and ketone groups, respectively, while $1690-1710 \mathrm{~cm}^{-1}$ regions related to due to $\mathrm{C}=\mathrm{O}$ stretching of $\mathrm{COOH}$ and ketonic $\mathrm{C}=\mathrm{O}$. A shoulder at $1650 \mathrm{~cm}^{-1}$ due to stretching of $\mathrm{C}=\mathrm{C}$ bonds present in aromatic or asymmetric alkenes conjugated with $\mathrm{C}=\mathrm{O}$ or carboxylate, and $1540 \mathrm{~cm}^{-1} \mathrm{region}$ corresponded to amide II band (i.e. $\mathrm{C}=\mathrm{N}$ stretching, $), 1240 \mathrm{~cm}^{-1}\left(\mathrm{C}-\mathrm{O}\right.$ stretching), $450 \mathrm{~cm}^{-1}$ was supposed to be due to S-S bonds (Kang et al., 2002; Fan et al., 2006; Qi et al., 2012). Therefore, it should be noted that within the present study, the characteristics of the functional groups of the LHA and SHA molecules were basically 
similar.

However, the vibrational forces in the relative distribution of each functional group, have some differences, hence the decrease and stretching of some bands of SHA (See Figure 2).

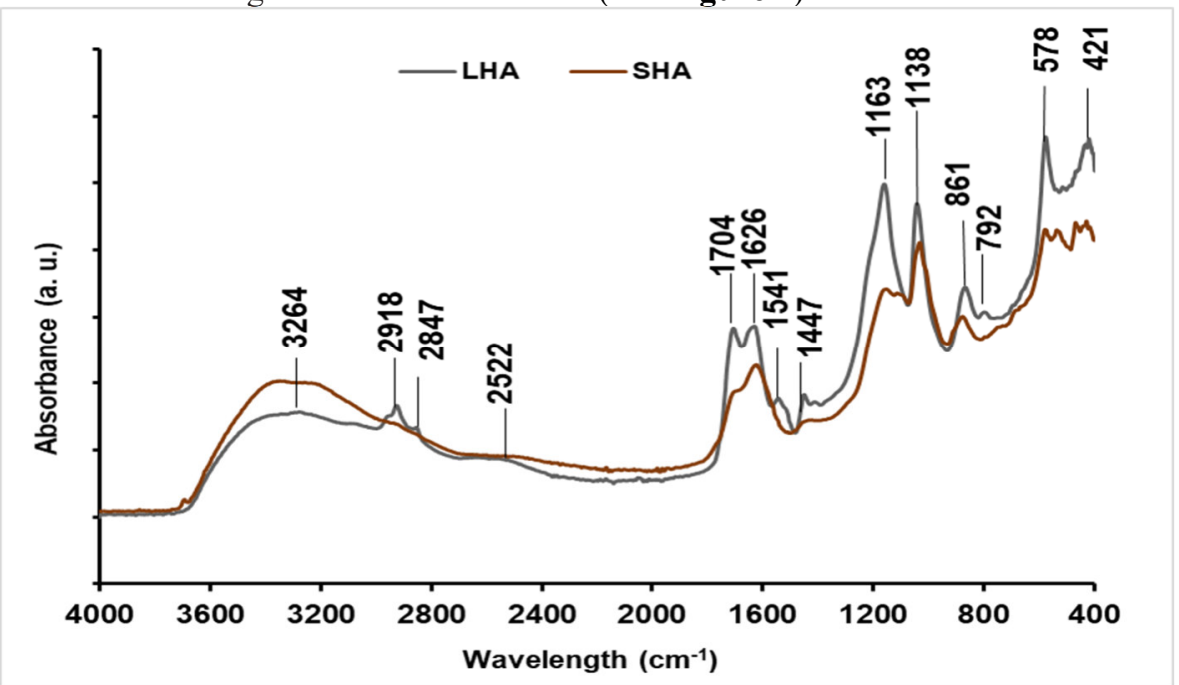

Figure 2 : DRIFT spectra of leachate humic acid (LHA) and synthetic humic acid (SHA).

\section{Conclusion}

In this work, we characterized the leachate from the Landfill of Akouédo despite the completion of filling operations. The Physico-chemical composition of the raw leachate suggested a stabilized landfill, with high $\mathrm{pH}$ values (i.e. $~ 8.85 \pm 0.03)$. The study revealed a weak load of inorganic pollutants $\left(\mathrm{NH}_{4}^{+}, \mathrm{NO}_{2}^{-}, \mathrm{NO}_{3}^{-}\right)$, compared to the FEPA's standard (1991). The stabilization of the landfill was confirmed by a very low $\mathrm{BOD}_{5} / \mathrm{COD}$ ratio which was approximately $0.1 \pm 0.05$. Metallic trace element contents (i.e. Iron, Copper, Nickel, Zinc and Lead) were also below FEPA's standard (1991). The study showed that organic content of the leachate was predominantly humic acid since fulvic acid was less than $10 \%$ in the leachate. This was confirmed through DRIFT analyses which showed that the characteristics of the functional groups of the LHA and SHA molecules were basically similar. The data on the humic substance (HS) characteristics shown in the results of the landfill leachate can be used in several related research areas, such as the optimization of leachate treatment processes and the remediation of groundwater contaminated with leachate.

\section{Acknowledgements}

This work was supported by UNESCO Regional Office for Eastern Africa.

We gratefully acknowledge Prof. DJOUFAC WOUMFO Emmanuel (Yaoundé I University) for the supervision, Dr. MBEY Jean Aimé (Yaoundé I University) for this analysis and the research team of the applied inorganic chemistry laboratory of Yaoundé I University. We thank the Sanitation and Environmental Engineering research team members (University of Nangui Abrogoua) for their help during the article's redaction.

\section{Conflicts of Interest}

The authors do not declare any conflict of interest with respect to the publication of this article.

\section{References}

Adjiri, O. A., Gone, D. L., Kouame, I. K., Kamagate, B., \& Biemi, J. (2008). La caractérisation de la pollution chimique et microbiologique de l'environnement de la décharge d'Akouédo, Abidjan (Côte d'Ivoire). International Journal of Biology and Chemical Science, 2(4), 401 - 410.

AFNOR, (1990). Eaux : Méthodes d'essais, recueil de normes franc, aises. Association Franc, aise de Normalisation, AFNOR, - 4e éd. Paris. Paris : Association française de normalisation, 1, 15-735.

APHA, (American Public Health Association), (1989). Standard Methods for the Examination of Water and Wastewater, Part 3, Determination of Metals. 17th, American Public Health Association, Washington DC, $164 \mathrm{p}$.

Baccini, P., Henseler, G., Figi, R., \& Belevi H. (1987). Water and element balances of municipal solid waste landfills. Waste Management \& Research, 5, 483-499.

Castagnoli, O., Musmeci, L., Zavattiero, E., \& Chirico, M. (1990). Humic substances and humification rate in a municipal refuse disposed of in a landfill. Water, Air, and Soil Pollution, 53, 1-12.

Chian, E. S. K., \& Dewalle, F. B. (1976). Sanitary landfill leachates and their treatment. Journal Environmental 
Engineering, ASCE, 102 (2), 411-431.

Fan H-J., Shu H-Y., Yang H-S., Chen W-C. (2006). Characteristics of landfill leachates in central Taiwan. Sci. Tot. Environ. $361: 25-37$.

FAO, (Food and Agriculture Organization of the United Nations) (1985). Integrating crops and livestock in West Africa. FAO Animal Production and Health paper, 41 (92-5), 101443-4.

FEPA, (Federal Environmental Protection Agency) (1991). National Interim Guidelines and Standards for Industrial Effluents and Water Quality Tests. FEPA, 32 - 59.

Gevalor, (2015). Etude sur la valorisation des déchets organiques dans le district d'Abidjan en vue de la réduction de polluants climatiques à courte durée de vie. Rapport final, $129 \mathrm{p}$.

Griffiths, P. R., \& Fuller, M. P. (1982). Mid-infrared spectrometry of powdered samples. In 'Advances in lnfrared and Raman Spectroscopy'. (Eds R. J. H. Clark and R. E. Hester.), 9 : 1 - 2.

Hach, (2014). Water Analysis Made Simple. International Edition Master Catalog, 412p.

Hecht, H. G. (1980). Quantitative analysis of powder mixtures by diffuse reflectance. Journal of Applied Spectroscopy, 34, 161-164.

Kang, Ki-H., Shin, H. S., \& Park, H. (2002). Characterization of humic substances present in landfill leachates with different landfill ages and its implications. Water Research, 36, 4023-4032.

Kouassi, A. M., Nassa, R. A., Yao, K. B., Kouame, K. F. \& Biemi, J. (2018). Modelisation statistique des pluies maximales annuelles dans le district d'Abidjan (sud de la Cote d'Ivoire). Revue des sciences de l'eau / Journal of Water and Science, 31 (2) , 147-160. https://doi.org/10.7202/1051697ar.

Kouassi, E. A., Ahoussi, K. E., Koffi, Y. B., Soro, N., Kouame, I. K., \& Biemi J. (2014). Caractérisation physico-chimique du lixiviat d'une décharge de l'Afrique de l'ouest : cas de la décharge d'Akouédo, (Abidjancôte d'ivoire). Journal Larhyss, 19, 63 - 74.

Kouamé, I. K., Goné, D. L., Savané, I., Kouassi, E. A., Koffi, K, Goula, B. T. A., \& Diallo, M. (2006). Mobilité relative des métaux lourds issus de la décharge d'Akouédo et risque de contamination de la nappe du continental terminal, (Abidjan - Côte d'Ivoire). Afrique Science, 02 (1), 39 - 56.

Kurniawan, T. A., Lo Wai, H., \& Chan, G. Y.S. (2006). Physico-chemical treatments for removal of recalcitrant contaminants from landfill leachate. Journal of Hazardous Materials, 129, 80-100.

Qi, G., Yue, D., \& Nie, Y. (2012). Characterization of humic substances in bio-treated municipal solid waste landfill leachate. Frontiers of Environmental Science \& Engineering, 6(5), 711-716.

Li, X. Z., \& Zhao, Q. L. (2002). MAP precipitation from landfill leachate and seawater bitter waste. Environmental Technology, 23, 989-1000.

Mugo, S. M., \& Bottaro, C. S. (2004). Characterization of humic substances by matrix-assisted laser desorption/ionization time-of-flightmass spectrometry. Rapid Communication Mass Spectrometry, 18, 237582.

Naveen, B. P., Mahapatra, D. M., Sitharam, T. G., Sivapullaiah, P. V., \& Ramachandra T. V. (2017). Physico-chemical and biological characterization of urban municipal landfill leachate. Environmental Pollution, 220, 1-12.

Sang, N., Han, M., Li, G. K., \& Huang, M. (2010). Landfill leachate affects metabolic responses of Zea mays L. seedlings. Waste Management, 30, 856-862.

Schnitzer, M., Khan, S. U. (1972). Humic substances in the environment. New York : Marcel Dekker, $203-251$.

Reuschenbach, P., Pagga, U., \& Strotmann, U. (2003). A critical comparison of respirometric biodegradation tests based on OECD 301 and related test methods. Water Research., 37 (7), 1571-1582.

Tałałaj, I. (1998). Quality of underground waters in the vicinity of municipal landfills (In Polish). Jakość wód gruntowych wokół wysypisk odpadów komunalnych. W: II Forum Inżynierii Ekologicznej "Monitoring środowiska"' red. Wiatr I., Marczak H. Nałęczów, 640p.

Tahiri, A., Richel, A., Destain, J., Druart, P., Thonart, P., \& Ongena, M. (2016). Comprehensive comparison of the chemical and structural characterization of landfill leachate and leonardite humic fractions. Analytical and Bioanalytical Chemistry, 408,1917-1928.

Thurman, E.M., Malcolm, R.L. (1981). Preparative isolation of aquatic humic substances. Environmental Science and Technology, 15(4), 463-476.

Wang, F., Smith, D.W., \& El-Din, G.M. (2003). Application of advanced oxidation methods for landfill leachate treatment - a review. Journal of Environmental Engineering and Science, 2, 413-427.

Yao-Kouassi, Q. C. (2010). A la recherche d'une synergie pour la gestion des déchets ménagers en Côte d'Ivoire : cas du district d'Abidjan. Thèse de Doctorat à l'Université du Maine, France, 305p.

Zalaghi, A., Lamchouri, F., Toufik, H., \& Merzouki, M. (2014). Valorisation des matériauxnaturelsporeux dans le traitement des Lixiviats de la décharge publique non contrôlée de la ville de Taza, Maroc. Journal of Materials and Environmental Science, 5 (5), 1643 - 1652.

Zhao, R., Novak, J. T., \& Goldsmith, C. D. (2012). Evaluation of on-site biological treatment for landfill leachates and its impact: a size distribution study. Water Research, 46, 3837-3848. 